\title{
Analisis Kualitas Soal Try-Out Bahasa Inggris SMP di Kota Makassar Berdasarkan Teori Respon Butir
}

\author{
Achmad Shabir \\ Program Studi Penelitian dan Evaluasi Pendidikan, \\ Program Pascasarjana Universitas Negeri Makassar, \\ Gunung Sari, Sulawesi Selatan, Indonesia. \\ Alamat e-mail: achmadshabir@gmail.com
}

\begin{abstract}
The aim of this study was to describe the quality of English testing intrument used in Try Out National Exam conducted by 40 Junior High Schools in Makassar-Sulawesi Selatan, using Item Response Theory (IRT) especially based on one (1PL), two (2PL), and three (3PL) parameters models. The data consist of 1.267 student's answer sheets and the test has 50 multiple choice items. Results showed that the test is preferably good at both item difficulty and item dicrimination as suggest by 1PL and 2PL estimation. But at 3PL estimation, the test unable to discriminate students ability, while $38 \%$ of the items were easy to guess.
\end{abstract}

Keywords: Item response theory; English testing; Try out of national exam.

\section{Latar Belakang}

Ujian Nasional (UN) adalah kegiatan pengukuran dan penilaian kompetensi peserta didik secara nasional pada jenjang pendidikan menengah. Ujian Nasional bertujuan menilai pencapaian kompetensi lulusan secara nasional pada mata pelajaran tertentu dalam kelompok mata pelajaran ilmu pengetahuan dan teknologi. Hasil Ujian Nasional digunakan sebagai 1). Pemetaan mutu program dan/atau satuan pendidikan; 2). Dasar seleksi masuk jenjang pendidikan berikutnya; 3). Penentuan kelulusan peserta didik dari satuan pendidikan; 4). Dasar pembinaan dan pemberian bantuan kepada satuan pendidikan dalam upaya meningkatkan mutu pendidikan.

Setiap jelang Ujian Nasional (UN) kerap dilakukan semacam simulasi ujian yang akrab disebut tryout atau simulasi ujian. Try out ini menjadi sangat populer dan dilaksanakan hampir di semua sekolah. Lembaga-lembaga bimbingan belajar hingga organisasi mahasiswa kerap melaksanakan try out untuk membantu para siswa menghadapi UN. Beberapa situs internet bahkan menyediakan try out UN via online.

Dalam try out, siswa dihadapkan dalam situasi yang sebisa mungkin mirip dengan UN. Hingga soal pun diupayakan semirip mungkin dengan soal UN. Pengalaman mirip UN konon dapat membantu siswa lebih siap untuk menghadapi UN sebenarnya. Meski pada dasarnya, simulasi jelas sangat berbeda dengan ujian sebenarnya, dimana siswa bisa merasakan kegelisahan yang tidak disediakan dalam simulasi. Begitupun dengan soal yang digunakan dalam simulasi, meski mirip, namun tak mungkin benar-benar sama dengan soal UN.

melalui Dinas Pendidikan juga


menyusun sebuah program Try-Out UN bagi SMP di Kota Makassar. Penyelenggaraan Try-Out SMP di Kota Makassar merupakan kegiatan tahunan dan bersifat wajib. Pendanaan pelatihan ini ditanggung masingmasing sekolah dengan biaya yang cukup besar.

Sayangnya, sejauh ini belum ada riset yang mampu menjelaskan sejauhmana keefektifan penyelenggaraan program tersebut. Salah satu aspek yang menjadi fokus dalam penelitian ini ialah kualitas instrumen yang digunakan atau dalam hal ini kualitas tes objektif pilihan ganda yang digunakan dalam Try-Out. Soal ini dikembangkan oleh pihak Musyawarah Guru Mata Pelajaran (MGMP) yang telah dianggap kapabel dan ditunjuk oleh pihak pemangku kebijakan, dalam hal ini Dinas Pendidikan Kota Makassar.

Fenomena penyelenggaraan Try-Out sejauh ini, masih menyimpan kesenjangan antara kenyataan yang ditemui dengan harapan. Soal yang digunakan diragukan kualitasnya. Soal Try-Out Bahasa Inggrism misalnya, dikembangkan oleh 4 orang guru MGMP yang dianggap berpengalaman. Sayangnya, proses validasi dilakukan oleh pengembang soal itu sendiri sehingga bertentangan dengan prinsip pengembangan instrumen.

Soal yang digunakan juga belum pernah ditindak lanjuti hingga pada analisis kualitas soal. Penyelenggaraan Try-Out selama ini hanya sampai pada rekapitulasi skor akhir peserta, sedangkan usaha untuk memperoleh informasi terkait kualitas soal yang digunakan cenderung tidak pernah dilakukan.

Kelemahan ini diperkuat hasil penelitian Enang (2014) yang menemukan bahwa Soal Seleksi Penerimaan Peserta Didik Baru SMP di Kota Makassar yang sejatinya juga merupakan buatan MGMP SMP Kota Makassar masih berada pada kategori kurang baik. Mardawiah (2011) juga menyimpulkan bahwa secara umum, kualitas Soal Try-Out IPA SMP di Kota Makassar masih tergolong kurang baik.

\subsection{Teori Respon Butir}

Dalam melakukan analisis kualitas soal Try-Out, peneliti menerapkan teori respon butir. Pendekatan ini dipilih karena kelebihan yang dimiliki yaitu teori ini membebaskan responden dan butir dari interdependensi, sehingga taraf sukar butir tidak lagi bergantung kepada kemampuan responden. Sebaliknya, kemampuan responden juga tidak lagi bergantung kepada taraf sukar butir. Melalui independensi di antara taraf sukar butir dan kemampuan responden, dapat dipilih butir yang cocok dengan responden.

Kelebihan lainnya, kesesuaian antara karakteristik tes dengan konsep teoretis dalam teori respon butir. Mengingat bahwa Try-Out merupakan kegiatan yang berskala besar dan melibatkan peserta yang sangat banyak, sehingga pemilihan teori respon butir dianggap paling tepat.

Teori Respon Butir (Item Response Theory disingkat IRT) dinamai juga sebagai Teori Ciri Laten (Latent Trait Theory disingkat LTT) atau Lengkungan Karakteristik Butir (Item Characteristic Curve disingkat ICC).

Teori ini dimunculkan pertama kali oleh Frederic M. Lord dalam disertasinya pada 1952 yang dikenal dengan teori sekor tes. Selanjutnya, 
Allan Birnbaum mengembangkan dasar statistik untuk model teori respon butir pada tahun 1957. Pada tahun 1960, Georg Rasch, seorang matematikawan Denmark mengembangkan model probabilistik untuk tes inteligensi dan tes pencapaian belajar. Model ini dikenal dengan Model Rasch yang selanjutnya dikembang-kan di Amerika Serikat mulai tahun 1967 oleh Benyamin Wrigth dan pengikutnya di Universitas Chicago (Mardapi, 1991: 3)

Menurut Sudaryono (2013) pada hakikatnya IRT bertujuan untuk mengatasi kelemahan yang terdapat pada pengukuran klasik. Pada IRT, peluang jawaban benar yang diberikan siswa, ciri atau parameter butir, dan ciri atau parameter peserta tes dihubungkan melalui suatu model formula yang harus ditaati baik oleh kelompok butir tes maupun kelompok peserta tes (Hambleton \& Rogers, 1991).

Artinya, butir yang sama terhadap peserta tes yang berbeda harus tunduk pada aturan rumus itu, atau peserta tes yang sama terhadap butir tes yang berbeda juga harus patuh terhadap rumus tersebut. Dalam proses semacam ini terjadilah apa yang disebut invariansi di antara butir tes dan peserta tes. Pada pengukuran modern, taraf sukar butir tidak dikaitkan langsung dengan kemampuan responden.

Perbedaan mendasar antara pengukuran klasik dengan pengukuran modern terletak pada invariansi pensekoran, di mana pensekoran modern adalah invarians (tidak berubah atau tetap) terhadap butir tes serta terhadap peserta tes. Lebih lanjut Lord (1990: 121) menyebutkan, invariansi parameter-parameter butir tes melalui kelompok peserta tes merupakan karakteristik yang paling penting dari IRT. Pada umumnya dikatakan bahwa indeks kesukaran butir tes sebagai proporsi jawaban yang benar sehingga sukar untuk membayangkan bagaimana indeks kesukaran tes dapat menjadi invarian terhadap kelompok peserta tes dari tingkat kemampuan yang berbeda.

Teori responsi butir perlu menentukan model karakteristik butir yang digunakan. Model karakteristik butir dapat berbentuk satu parameter logistik (1PL), dua parameter logistik (2PL), tiga parameter logistik (3PL), atau model lain. Pembahasan dalam penelitian ini menggunakan model 3PL yang dikembangkan oleh Allan Birnbaum dan Frederic M Lord.

Model 3PL dipilih karena keunggulan fitur yang dimiliki atas model 1PL yang dicetuskan Georg Rasch. Dalam banyak literatur Model Rasch dianggap unggul dari segi akurasi estimasi karena hanya mengestimasi 1 parameter logistik yakni taraf sukar butir (b).

Namun asumsi bahwa daya beda (a) adalah setara bagi semua butir soal, memberikan kekurangan bagi model Rasch karena kenyataan di lapangan menunjukkan hampir tidak mungkin menjumpai soal-soal dengan daya beda yang sama (Bock, 1997).

Selain itu, informasi mengenai daya beda soal diperlukan dalam menyusun suatu tes untuk menjamin reliabilitas tes yang tinggi dan distribusi skor yang diinginkan. Divgi (1986) bahkan menyimpulkan bahwa model Rasch tidak cocok digunakan untuk tes dengan format pilihan ganda, utamanya karena model Rasch mengasumsikan tidak ada peserta tes yang menjawab soal dengan benar 
dengan cara menebak $(\mathrm{c}=0)$. Berdasarkan studinya ia menemukan bahwa model dengan lebih banyak parameter fit lebih baik dibandingkan model Rasch.

Embretson dan Reise (2000), meskipun mengakui kelebihan model Rasch, tidak merekomendasikan model Rasch digunakan untuk semua situasi. Menurut mereka, untuk alat ukur psikologi adanya daya beda soal yang bervariasi tidak dapat dihindarkan. Oleh karena itu, mereka merekomendasikan untuk menggunakan model yang lebih kompleks daripada model Rasch.

Mereka beragumen bahwa hal ini akan mencegah didropnya soal-soal yang penting yang mungkin akan menyebabkan berubahnya konstruk yang akan diukur. Meskipun untuk hal ini dapat diperdebatkan bahwa dasar dalam membuang soal seharusnya tidak hanya berdasarkan kriteria statistik.

Kritik terhadap model Rasch pada umumnya adalah karena model Rasch mempunyai kemungkinan lebih kecil untuk fit dengan data. Dengan kata lain, model Rasch tidak dapat menerangkan data dengan baik karena kesederhanaan pengukurannya.

Di sisi lain model 2PL dan 3PL unggul dari segi penyajian datanya. Estimasi parameter taraf sukar butir (b) dan daya beda butir (a) pada model 2PL memberikan gambaran data yang lebih kompleks dibanding data sederhana hasil estimasi model Rasch. Begitupun model 3PL memberikan gambaran data yang lebih komplit karena turut memasukkan parameter tebakan (c) dalam estimasinya. Model 2PL dan 3PL dikenal juga dengan nama model Birnbaum.
Rogers (1999) mengemukakan model 3PL juga mempunyai keterbatasan dalam mengestimasi parameter, yaitu memerlukan jumlah subjek/sampel dan jumlah soal yang besar. Penelitian ini sendiri menggunakan sampel yang tergolong besar dan jumlah butir soal yang cukup banyak.

Hambleton, Swaminathan \& Rogers (1991: 12) merumuskan Model 1PL sebagai berikut:

$$
P i(\theta)=\frac{e^{\left(\theta-b_{i}\right)}}{1+e^{\left(\theta-b_{i}\right)}}
$$

dengan $\mathrm{i}=1,2,3, \ldots \mathrm{n}$

$$
\begin{aligned}
& \text { Keterangan: } \\
& \operatorname{Pi}(\theta)= \text { Peluang menjawab } \\
& \text { benar peserta yang } \\
& \text { berkemampuan 0 pada } \\
& \text { butir ke i } \\
& b i \quad= \text { Tingkat kesukaran butir } \\
& \text { ke- } i \\
& e \text { Bilangan natural yang } \\
& \text { bernilai 2.712 } \\
& n= \text { Jumlah butir soal } \\
& n= \text { Kostanta bernilai } 1.7 \\
& \text { sebagai simpangan baku } \\
& \text { distribusi logistik }
\end{aligned}
$$

Persamaan tersebut merupakan cara yang digunakan untuk mengestimasi butir dengan 1 parameter. Melalui persamaan tersebut juga dapat digunakan untuk menggambarkan kurva karakteristik butir ke- $i$ yang menggambarkan probabilitas/peluang peserta $(\theta)$ menjawab butir soal dengan benar. Parameter bi merupakan suatu titik pada skala kemampuan agar peluang menjawab benar sebesar 50\%. Semakin besar nilai bi, maka semakin besar kemampuan yang diperlukan untuk menjawab benar dengan peluang 
$50 \%$ atau dengan kata lain semakin besar nilai parameter bi, maka semakin sulit butir soal tersebut.

Sementara model 2PL menitik beratkan selain pada tingkat kesukaran butir, juga menitik beratkan pada daya beda butir soal. Untuk itu faktor tebakan masih diasumsikan sama dengan 0 atau tidak ada tebakan. Rumusnya sebagai berikut:

$$
\operatorname{Pi}(\theta)=\frac{e^{D a_{i}\left(\theta-b_{i}\right)}}{1+e^{D a_{i}\left(\theta-b_{i}\right)}}
$$

dengan $\mathrm{i}=1,2,3, \ldots \mathrm{n}$

Keterangan:

$$
\begin{aligned}
\operatorname{Pi}(\theta)= & \begin{array}{l}
\text { Peluang menjawab } \\
\text { benar peserta yang } \\
\text { berkemampuan 0 pada } \\
\text { butir ke i }
\end{array} \\
a i \quad= & \begin{array}{l}
\text { Parameter daya beda } \\
\text { butir }
\end{array} \\
b i \quad= & \begin{array}{l}
\text { Tingkat kesukaran butir } \\
\text { ke- } i
\end{array} \\
e \quad= & \text { Bilangan natural yang } \\
& \text { bernilai } 2.712 \\
n= & \text { Jumlah butir soal } \\
D= & \text { Kostanta bernilai } 1.7 \\
& \text { sebagai simpangan baku } \\
& \text { distribusi logistik }
\end{aligned}
$$

Sementara model 3PL mengontrol parameter tingkat kesukaran, daya beda dan tebakan secara bersama-sama. Rumusnya sebagai berikut:

$$
\operatorname{Pi}(\theta)=c+(1-c) \frac{1}{1+e^{-a_{i}\left(\theta-b_{i}\right)}}
$$

dengan $\mathrm{i}=1,2,3, \ldots . . \mathrm{n}$

Keterangan:

$$
\operatorname{Pi}(\theta)=\underset{\text { peluang menjawab benar }}{\text { perta }} \text { yang }
$$

berkemampuan 0 pada butir ke i

$a i=$ Parameter daya beda butir

$b i=$ Tingkat kesukaran butir ke- $i$

$c=$ Parameter tebakan

$e=$ Bilangan natural yang bernilai 2.712

$n=$ Jumlah butir soal

Kelebihan lain dari IRT adalah

fitur fungsi informasi. Menurut Susetyo (2007: 44) fungsi informasi merupakan suatu keterangan atau angka yang menunjukkan tinggi rendahnya nilai informasi yang dimiliki oleh butir atau tes. Nilai fungsi informasi berisikian kecocokan antara parameter kemampuan peserta tes $(\theta)$ dengan parameter butir. Nilai informasi suatu butir atau tes dapat diperoleh melalui perhitungan manual dan dapat pula dilihat pada grafik sepanjang rentang nilai kemampuan peserta. Fungsi informasi terdiri atas dua yakni fungsi informasi butir dan fungsi informasi tes.

\section{Metode}

\subsection{Sampel Penelitian}

Jenis penelitian ini adalah penelitian deskriptif kuantitatif, yaitu jenis penelitian yang bertujuan menggambarkan keadaan, gejala, atau kelompok tertentu berdasarkan data angka yang diperoleh dari hasil tes. Gejala yang dimaksud adalah Soal TryOut Mata Pelajaran Bahasa Inggris SMP di Kota Makassar Tahun Ajaran 2013/2014.

Semua butir Soal Try-Out Mata Pelajaran Bahasa Inggris sejumlah 50 butir soal menjadi objek penelitian. Besar sampel dalam penelitian ini adalah 1267 lembar jawaban peserta tes dari total 20 sekolah. Sampel dipilih menggunakan metode purposive atau 
secara sengaja berdasarkan pertimbangan Sudaryono (2013:2) bahwa untuk mendapatkan hasil analisis yang lebih baik dalam aplikasi teori respon butir, maka seharusnya jumlah peserta (lembar jawaban) minimal 400 orang, namun semakin banyak sampel maka hasil analisis soal akan semakin maksimal. Berikut penjabaran sampelnya:

Tabel 2.1 Deskripsi Penyampelan

\begin{tabular}{|l|l|c|}
\hline No & Sekolah & $\begin{array}{l}\text { Sampel } \\
\text { (LJK) }\end{array}$ \\
\hline 1 & SMPN 3 Makassar & 82 \\
\hline 2 & SMPN 4 Makassar & 79 \\
\hline 3 & SMPN 5 Makassar & 87 \\
\hline 4 & SMPN 6 Makassar & 60 \\
\hline 5 & SMPN 7 Makassar & 81 \\
\hline 6 & SMPN 8 Makassar & 80 \\
\hline 7 & SMPN 9 Makassar & 72 \\
\hline 8 & SMPN 10 Makassar & 47 \\
\hline 9 & SMPN 11 Makassar & 36 \\
\hline 10 & SMPN 12 Makassar & 49 \\
\hline 11 & SMPN 13 Makassar & 61 \\
\hline 12 & SMPN 14 Makassar & 57 \\
\hline 13 & SMPN 15 Makassar & 56 \\
\hline 14 & SMPN 16 Makassar & 55 \\
\hline 15 & SMPN 17 Makassar & 73 \\
\hline 16 & SMPN 18 Makassar & 55 \\
\hline 17 & SMPN 19 Makassar & 71 \\
\hline 18 & SMPN 20 Makassar & 57 \\
\hline 19 & SMPN 21 Makassar & 62 \\
\hline 20 & SMPN 22 Makassar & 47 \\
\hline Total Sampel & $\mathbf{1 . 2 6 7}$ \\
\hline $\mathbf{2}$ & Teknk Analsis Data \\
\hline
\end{tabular}

\subsection{Teknik Analisis Data}

Analisis data dilakukan secara kuantitatif deskriptif dengan menelaah karakteristik butir setiap butir soal atau item berdasarkan teori respon butir. Analisis ini dilakukan dengan menggunakan bantuan aplikasi program (software) komputer R versi 3.1.0. Program ini dapat digunakan untuk menganalisis butir soal dengan menggunakan bahasa pemrograman dengan kode script tertentu.

Program $\mathrm{R}$ memiliki berbagai macam package yang dapat diunduh secara gratis sesuai dengan kebutuhan pengembang atau pengguna. Namun dalam penelitian ini, package yang digunakan ialah package "ltm" yang merupakan singkatan dari Latent Trait Model.

\subsection{Kriteria Penelitian}

Untuk memberikan interpretasi terhadap hasil analisis butir yang diperoleh, maka berikut ini disajikan kriteria kualitas soal berdasarkan teori respon butir:

\section{Unidimensi}

Unidimensi dilakukan untuk memperoleh informasi bahwa tes hanya mengandung satu komponen dominan yang mengukur kemampuan peserta. Uji unidimensi dilakukan dengan estimasi Model Logistik 1 Parameter, 2 Parameter dan 3 Parameter. Kriteria yang digunakan untuk menginterpretasi pengujian tersebut ialah membandingkan $\mathrm{p}$ value denga $\alpha$. Jika $p$ value $<\alpha$ maka unidimensi terpenuhi.

\section{Independen Lokal}

Independen lokal menginginkan butir-butir soal independen satu sama lain. Artinya tidak berkorelasi tinggi antara butir satu dengan butir yang lainnya. Untuk mengestimasi hal tersebut dilakukan pembagian dua kelompok butir ganjil dan genap, kemudian dikrelasikan. Jika rab $<0.9$ maka asumsi independen lokal terpenuhi.

3. Goodness of Fit Test (Uji Kecocokan Model) 
Pengujian kecocokan model dilakukan pada semua butir soal yang telah direspon oleh peserta tes. Pengujian tersebut menggunakan statistic $\mathrm{Zij}$ yang berdistribusi khikuadrat. Kriteria pengujian tersebut ialah jika khi-kuadrat hitung > khikuadrat table maka butir soal tersebut cocok dengan model. Atau juga dapat menggunakan $\mathrm{p}$ value dengan criteria jika $\mathrm{p}$ value $<\alpha$ maka butir-butir soal tersebut fit atau cocok dengan model.

\section{Estimasi L 1 Parameter}

Tingkat kesukaran bervariasi, mulai dari -2 sampai +2 , nilai mendekati -2 menunjukkan bahwa butir soal tersebut semakin mudah. Nilai mendekati +2 menunjukkan butir soal tersebut semakin sulit.

\section{Estimasi L 2 Parameter}

Parameter ai (daya beda butir ke-i) pada skala $(-\infty,+\infty)$ dimana nilai positif menunjukkan bahwa butir tesbut memiliki daya beda yang berfungsi, begitupula nilai negatif menunjukkan bahwa butir tersebut memiliki daya beda yang tidak berfungsi.

\section{Estimasi L 3 Parameter}

Probabilitas menjawab butir dengan tebakan bergantung pada banyaknya opsi butir soal tersebut. Soal yang ideal ialah soal yang memiliki faktor tebakan (guessing) mendekati 0 . Jika faktor tebakan memiliki nilai di bawah $0.25(c<0.25)$ maka butir soal tersebut dapat dikategorikan baik.

\section{Fungsi Informasi}

Fungsi informasi (butir dan tes) sangat tergantung pada kemiringan (slope). Semakin besar nilai slope dan semakin kecil nilai variansi, maka semakin banyak banyak nilai informasi yang dihasilkan, sehingga hal tersebut berdampak pada semakin kecilnya kesalahan pengukuran.

\section{Hasil}

\subsection{Pengujian Asumsi Teori Respon Butir}

Dalam teori respon butir terdapat asumsi yang mesti dipenuhi dan diuji sebelum melakukan analisis butir soal, yaitu unidimensi dan independen lokal.

Pengujian unidimesi dilakukan dengan mengestimasi matrix of tertachoric correlations dengan kriteria: butir-butir tes tersebut memenuhi asumsi unidimensi jika $p$ value < alpha 0.05. Dari hasil pengujian diperoleh $\mathrm{p}$ value sebesar 0.0099. Koefisien ini lebih kecil dari pada alpha 0.05. Untuk itu asumsi unidimensi terpenuhi. Menurut Naga (1992: 164), uji unidimensi bertujuan mempertahan-kan invariansi. Kalau butir tes sampai mengukur lebih dari satu dimensi, maka jawaban terhadap butir itu merupakan kombinasi dari berbagai kemampuan peserta tes. Akibatnya, tidak lagi diketahui kontribusi dari setiap kemampuan terhadap jawaban peserta tes. Dengan mengganti butir tes atau kelompok peserta tes, tidak dapat lagi dipertahankan invariansi pada ukuran ciri butir tes dan pada ukuran ciri peserta tes. Ketidak-mampuan mempertahankan syarat invariansi ini bertentangan dengan tujuan teori responsi butir.

Edwards (2009: 515) menyebutkan, dalam praktiknya, tidak ada data (terkecuali simulasi) yang benarbenar unidimensional. Fokus pengecekan asumsi dimensional adalah apakah ada faktor tunggal yang 
menyediakan perkiraan yang cukup atau tidak, dalam data yang diamati.

Sedangkan pengujian independen lokal dimaksudkan untuk mengetahui apakah respon pada butirbutir yang berbeda bersifat independen atau tidak, yakni suatu kondisi di mana tidak ada hubungan yang pasti antara respon untuk butir-butir yang berbeda (Edwards, 2009: 515).

Dalam pengujian independen lokal, butir dikelompokkan menjadi dua: butir ganjil dan genap. Setelah itu dilakukan analisis korelasi antara parameter butir ganjil dengan parameter butir genap. Berikut hasil pengujiannya:

Tabel 3.1 Ringkasan Pengujian Independen Lokal

\begin{tabular}{cccc}
\hline Independen Lokal & Daya Beda (a) & Tingkat Kesukaran (b) & Tebakan (c) \\
\hline Koofisien Korelasi & 0.065 & 0.235 & 0.024 \\
\hline Status Korelasi & Rendah & Rendah & Rendah \\
\hline
\end{tabular}

Dari pengujian, diperoleh informasi bahwa asumsi independen lokal teruji. Nilai koefisien korelasi dari dua kelompok ganjil dan genap tidak berkorelasi yang cukup berarti. Artinya tidak ada hubungan yang pasti antara jawaban/respon peserta untuk butir-butir yang berbeda (independen).

\subsection{Pengujian Model Logistik 3 Parameter (Birnbaum Model)}

Tabel 3.2.1 menunjukkan hasil estimasi kualitas Soal Try-Out Bahasa Inggris berdasarkan Model Logistik 3 Parameter. Nilai $b_{i}$ atau indeks kesukaran butir yang baik berkisar dari -2 sampai 2. Nilai yang mendekati garis negatif menunjukkan bahwa butir tersebut terlalu mudah, begitupula semakin mendekati berada pada garis positif menunjukkan butir soal tersebut semakin sulit.

Tabel 3.2.1 Hasil Estimasi Kualitas Soal Try-Out Bahasa Inggris di SMP Kota Makassar ditinjau dari Model Logistik 3 Parameter

\begin{tabular}{cccccccc}
\hline Butir & $\begin{array}{c}\text { Tingkat } \\
\text { Kesukaran } \\
(\mathbf{b})\end{array}$ & $\begin{array}{c}\text { Daya } \\
\text { Beda } \\
(\mathbf{a})\end{array}$ & $\begin{array}{c}\text { Tebakan } \\
(\mathbf{c})\end{array}$ & Butir & $\begin{array}{c}\text { Tingkat } \\
\text { Kesukaran } \\
(\mathbf{b})\end{array}$ & $\begin{array}{c}\text { Daya } \\
\text { Beda } \\
(\mathbf{a})\end{array}$ & $\begin{array}{c}\text { Tebakan } \\
(\mathbf{c})\end{array}$ \\
\hline 1 & -0.744 & 1.494 & 0.132 & 26 & 0.733 & 2.277 & 0.226 \\
\hline 2 & 0.135 & 1.298 & 0.386 & 27 & 0.518 & 2.021 & 0.260 \\
\hline 3 & 0.220 & 2.238 & 0.236 & 28 & 0.746 & 2.294 & 0.352 \\
\hline 4 & 1.541 & 2.085 & 0.232 & 29 & 1.697 & 4.539 & 0.158 \\
\hline 5 & 0.317 & 2.702 & 0.309 & 30 & -0.214 & 0.990 & 0.121 \\
\hline 6 & 1.270 & 2.069 & 0.278 & 31 & -0.386 & 2.287 & 0.284 \\
\hline 7 & -1.790 & 3.059 & 0.000 & 32 & -2.952 & -3.134 & 0.239 \\
\hline 8 & 1.815 & 2.379 & 0.255 & 33 & 0.354 & 0.980 & 0.162 \\
\hline 9 & 1.131 & 1.938 & 0.344 & 34 & 1.281 & 0.473 & 0.169 \\
\hline 10 & -0.539 & 2.311 & 0.260 & 35 & 1.921 & 8.432 & 0.266 \\
\hline 11 & 1.363 & 3.549 & 0.215 & 36 & 1.360 & 2.308 & 0.141 \\
\hline 12 & 0.830 & 2.220 & 0.191 & 37 & 2.291 & 1.145 & 0.189 \\
\hline 13 & 0.381 & 2.247 & 0.415 & 38 & 0.401 & 0.105 & 0.000 \\
\hline 14 & 24.839 & 0.055 & 0.038 & 39 & 1.377 & 2.262 & 0.296 \\
\hline
\end{tabular}




\begin{tabular}{cccccccc}
\hline 15 & -1.226 & 2.008 & 0.000 & 40 & 2.562 & 1.410 & 0.317 \\
\hline 16 & 0.678 & 2.457 & 0.272 & 41 & 2.051 & 4.408 & 0.292 \\
\hline 17 & -1.795 & 2.375 & 0.000 & 42 & 2.067 & 12.36 & 0.175 \\
\hline 18 & 0.785 & 3.144 & 0.216 & 43 & 1.085 & 3.809 & 0.273 \\
\hline 19 & 0.305 & 1.628 & 0.317 & 44 & 0.794 & 0.592 & 0.000 \\
\hline 20 & 1.052 & 1.187 & 0.369 & 45 & -0.208 & 1.753 & 0.248 \\
\hline 21 & -1.985 & 1.297 & 0.000 & 46 & -3.410 & -0.397 & 0.000 \\
\hline 22 & -1.417 & 1.088 & 0.000 & 47 & -4.142 & -0.438 & 0.000 \\
\hline 23 & -1.031 & 1.064 & 0.000 & 48 & 2.806 & 0.960 & 0.269 \\
\hline 24 & -9.914 & -0.087 & 0.000 & 49 & -0.367 & 1.052 & 0.000 \\
\hline 25 & 1.191 & 0.371 & 0.000 & 50 & 1.871 & 1.397 & 0.234 \\
\hline
\end{tabular}

Sumber : Hasil Analisis Data

Dari estimasi ini ditemukan sebanyak 40 butir atau sekitar $80 \%$ soal Try-Out Bahasa Inggris di SMP Kota Makassar berada pada katagori baik, serta sebanyak 10 butir atau sekitar
20\% soal Try-Out Bahasa Inggris di SMP Kota Makassar berada pada kategori tidak baik atau buruk. Untuk lebih jelasnya informasi tersebut dapat diamati pada Tabel 4.3 berikut ini:

Tabel 3.2.2 Pengkategorian Kualitas Butir (Tingkat Kesukaran) Soal Try-Out Bahasa Inggris SMP di Kota Makassar ditinjau dari Model Logistik 3 Parameter.

\begin{tabular}{lllc}
\hline Kategori & \multicolumn{1}{c}{ Butir } & Jumlah & Persentase \\
\hline Baik & $1,2,3,4,5,6,7,8,9,10,11,12,13,15,16,17,18,19$, & 40 & $80 \%$ \\
& $20,21,22,23,25,26,27,28,29,30,31,33,34,35$ & & \\
& $36,38,39,43,44,45,49,50$ & & \\
\hline Tidak & $14,24,32,37,40,41,42,46,47,48$ & 10 & $20 \%$ \\
Baik & & & \\
\hline
\end{tabular}

Butir soal yang paling mudah dengan kualitas buruk adalah butir soal nomor 24. Kurva karakteristik butir (ICC) menunjukkan butir 24 lebih berpeluang besar dijawab benar oleh peserta yang berkemampuan rendah dibandingkan dengan peserta yang berkemampuan tinggi. Sementa-ra butir soal yang paling sulit dengan kualitas buruk adalah butir soal nomor
14. Butir ini menuntut kemampuan sangat tinggi untuk bisa dijawab dengan benar.

Lebih jelasnya berikut disajikan perbandingan kurva karakteristik butir soal tesebut dengan menyajikan butir yang mudah dengan kualitas buruk, sulit dengan kualitas buruk dan butir soal yang ideal sebagai berikut:
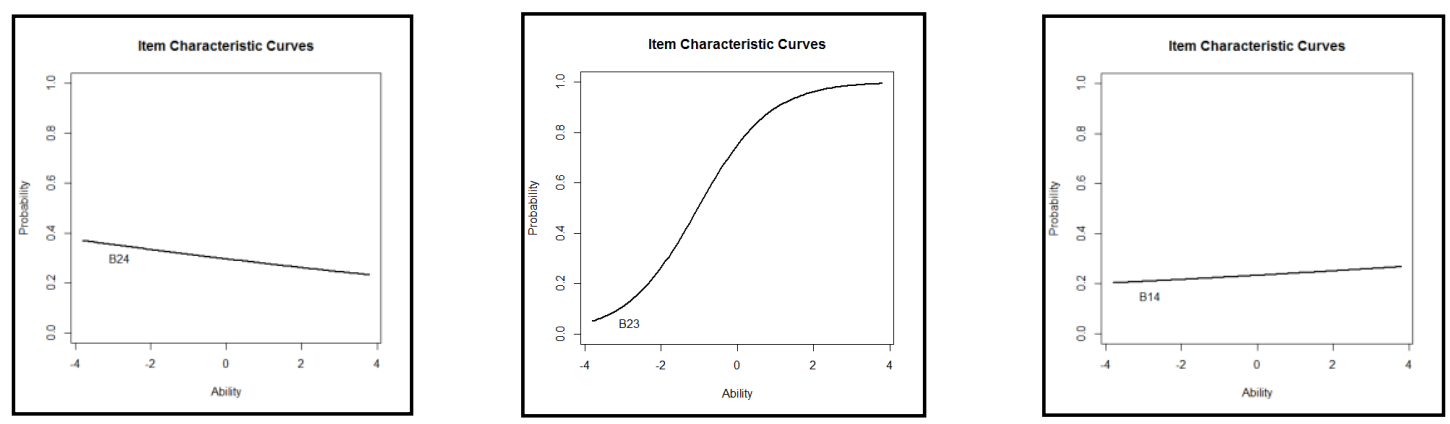
Butir 24 Termudah

(buruk)
Butir 23 Ideal

(baik)
Butir 14 Tersulit

(buruk)

Gambar 3.2.1 Perbandingan Kurva Karakteristik Butir Soal Termudah, Tersulit dan Ideal Try-Out SMP di Kota Makassar berdasarkan Model Logistik 3 Parameter

Pada teori respon butir, parameter daya beda $\left(\mathrm{a}_{\mathrm{i}}\right)$ didefenisikan pada skala kemampuan $(-\infty,+\infty)$. Hambleton, Swaminathan dan Rogers, (1991: 37) mengatakan koefisien daya beda $\left(\mathrm{a}_{\mathrm{i}}\right)$ yang negatif menunjukkan bahwa butir tersebut memiliki daya beda buruk, begitupula sebaliknya bahwa koefisien daya beda $\left(\mathrm{a}_{\mathrm{i}}\right)$ yang positif menunjukkan bahwa butir tersebut memiliki daya beda baik. Namun koefisien daya beda yang terlalu tinggi juga tidak dapat dijadikan tolok ukur untuk membedakan kemampuan peserta. Koofisien daya beda yang baik atau ideal berkisar $0 \mathrm{~s} / \mathrm{d}$ 2 .

Dari hasil estimasi sekitar 21 butir (42\%) soal memiliki daya beda butir yang baik, sisanya 29 butir (58\%) memiliki daya beda butir yang buruk atau tidak baik. Tabel 3.2.3 menunjukkan pengkategorian tersebut.

Tabel 3.2.3. Pengkategorian Kualitas Butir (Daya Beda) Soal Try-Out Bahasa Inggris SMP di Kota Makassar ditinjau dari Model Logistik 3 Parameter.

\begin{tabular}{clcc}
\hline \multicolumn{1}{c}{ Kategori } & \multicolumn{1}{c}{ Butir } & Jumlah & Persentase \\
\hline Baik & $1,2,9,14,19,20,21,22,23,25,30,33,34,37$, & 21 & $42 \%$ \\
& $38,40,44,45,48,49,50$ & & \\
\hline Tidak Baik & $3,4,5,6,7,8,10,11,12,13,14,15,16,17,18$, & 29 & $58 \%$ \\
& $24,26,27,28,29,31,32,35,36,39,41,42,43$, & & \\
& 46,47 & & \\
\hline
\end{tabular}

Menurut Fraley, Waller \& Brennan (2000: 353) butir yang memiliki daya beda rendah, relatif memiliki informasi yang sedikit dibanding butir yang memiliki daya beda tinggi. Butir yang memiliki daya beda rendah, kurva karakteristik butirnya juga cenderung landai atau kurang curam dibanding butir yang memiliki daya beda tinggi.

Berbeda dengan model 1PL dan 2PL, model 3PL mengontrol parameter tebakan (c). Tebakan (c) merupakan parameter yang menunjukkan peluang atau probabilitas suatu butir dijawab dengan benar oleh peserta tes melalui terkaan. Parameter tebakan tersebut 
berupa koofisien probabilitas (0-1) semakin koofisien tersebut mendekati 0 maka semakin baik butir tersebut, begitupula sebaliknya semakin koofisien $c_{i}$ mendekati 1 maka semakin buruk butir tersebut. Menurut
Hambleton, Swaminathan dan Rogers, (1991) bahwa butir dikatakan baik jika peluang terjadinya tebakan kurang dari $25 \%$ atau koofisien $c_{i}<0.25$. Berikut rinciannya:

Tabel 3.2.4 Pengkategorian Kualitas Butir (Faktor Tebakan) Soal Try-Out Bahasa Inggris SMP di Kota Makassar ditinjau dari Model Logistik 3 Parameter.

\begin{tabular}{clcc}
\hline Kategori & \multicolumn{1}{c}{ Butir } & \multicolumn{1}{c}{ Jumlah } & Persentase \\
\hline Baik & $1,3,4,7,11,12,14,15,17,18,21,22,23,24,25$, & 31 & $62 \%$ \\
& $26,29,30,32,33,34,36,37,38,42,44,45,46$, & & \\
& $47,49,50$ & & \\
\hline Tidak Baik & $2,5,6,8,9,10,13,16,19,20,27,28,31,35,39$, & 19 & $38 \%$ \\
& $40,41,43,48$ & & \\
\hline
\end{tabular}

Analisis terhadap kurva karekteriktik butir (ICC) menunjukkan butir soal nomor 13 memiliki peluang tebakan yang paling besar dengan koofisien parameter c sebesar 0.415 , dengan kata lain peluang peserta menjawab benar butir ini dengan cara menebak adalah sebesar $41.5 \%$. Sebaliknya butir 23 memiliki koofisien

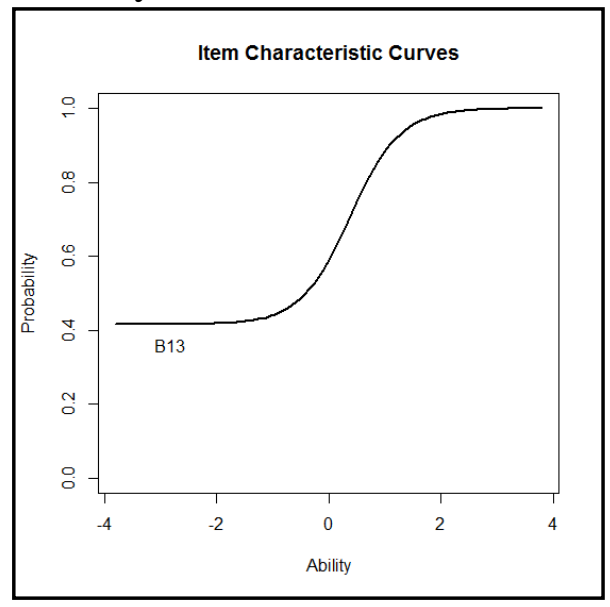

Butir 13 parameter c sebesar 0.000 . Ini berarti butir soal nomor 23 memiliki peluang jawaban benar dengan tebakan sebesar $0 \%$. Berikut disajikan kurva karakteristik butir dari kedua butir tersebut:

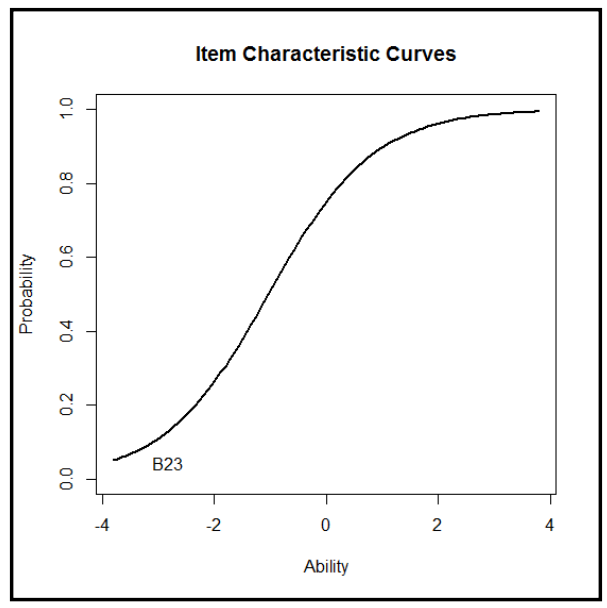

Butir 23

Gambar 3.2.2 Contoh Dua Butir dengan Parameter Tebakan yang Berbeda 


\subsection{Fungsi Informasi Tes}

Fungsi informasi tes menunjukkan seberapa maksimal informasi yang diberikan oleh suatu perangkat tes jika diberikan pada peserta berkemampuan tertentu. Berikut disajikan kurva fungsi informasi tes soal Try-Out SMP di Kota Makassar berdasarkan model 3PL:

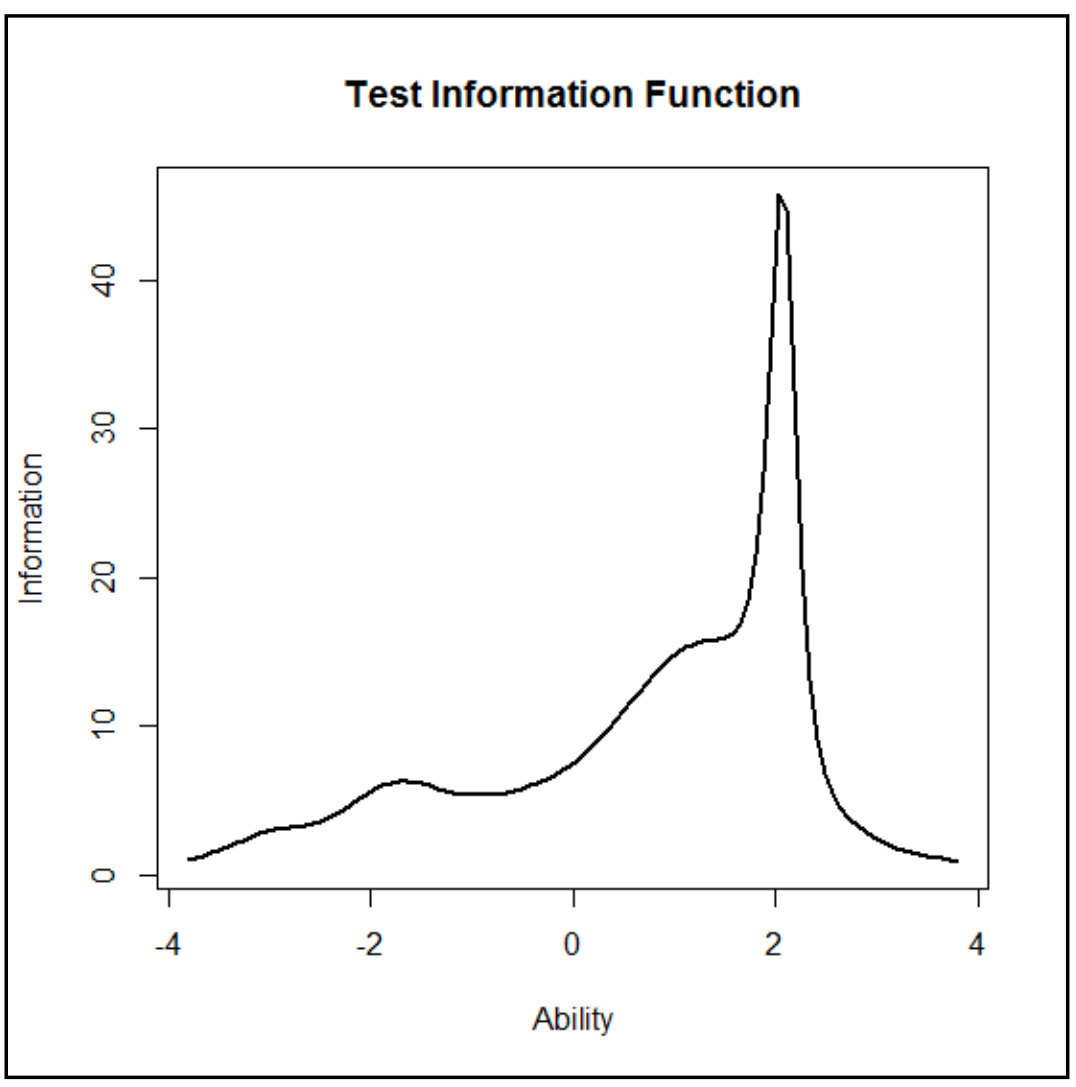

Gambar 3.3.1 Fungsi Informasi Tes Try-Out SMP di Kota Makassar berdasarkan Model Logistik 3 Parameter

Kurva diatas menunjukkan Tes Try Out Bahasa Inggris SMP di Kota Makassar akan memberikan informasi yang maksimal jika dikenakan pada peserta berkemampuan sekitar 1.9 hingga 2.2. Dengan kata lain tes tersebut cocok dikenakan pada peserta yang berkemampuan 1.9 hingga 2.2.

Fungsi informasi tes menunjukkan seberapa baik setiap level kemampuan diestimasi oleh instrumen tes. (Thorpe et al, 2007, p. 179 dalam Thorpe dan Favia, 2012: 7).

\subsubsection{Fungsi Informasi Butir}

Fungsi Informasi tes merupakan akumulasi dari semua Fungsi Informasi Butir sehingga gabungan dari semua Fungsi Informasi Butir akan melahirkan Fungsi Informasi Tes.

Berdasarkan Kurva Fungsi Informasi Butirnya, pada dasarnya Fungsi Informasi di setiap butir soal bervariasi, ada soal yang memberi informasi yang baik jika dikenakan pada peserta yang berkemampuan rendah, ada pula butir soal yang justru memberi informasi yang baik jika 
diberikan pada peserta yang berkemampuan tinggi.

Berikut disajikan kurva informasi butir Soal Try-Out Bahasa Inggris SMP di Kota Makassar:

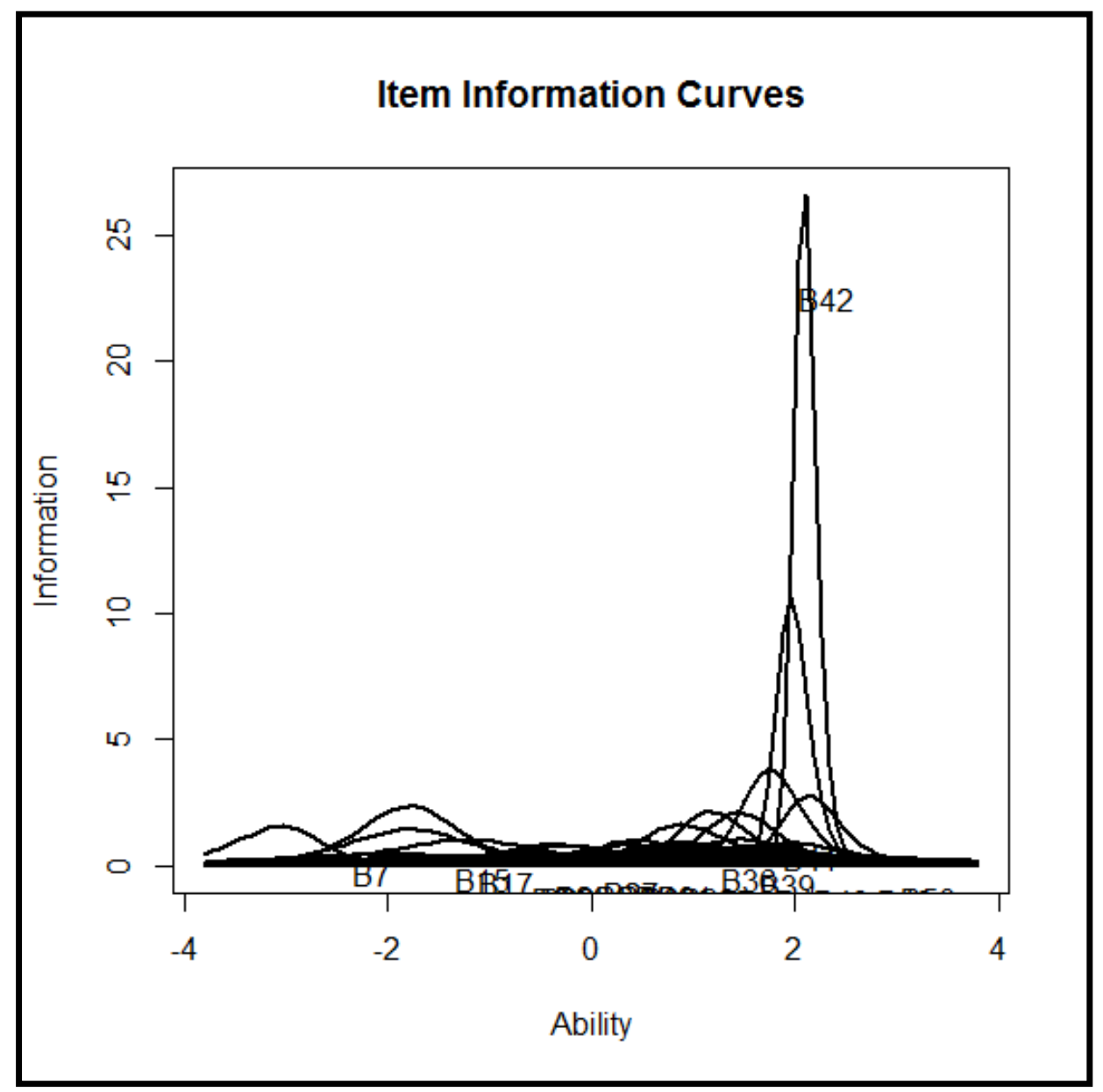

Gambar 3.3.2 Fungsi Informasi Butir Soal Try-Out SMP di Kota Makassar berdasarkan Model Logistik 3 Parameter

Fraley, Waller \& Brennan (2000: 352-353) menyebutkan, sebuah butir memberikan informasi lebih banyak pada titik trait kontinumnya, dimana theta $(\theta)$ sebanding/seimbang dengan tingkat kesulitan $\left(b_{i}\right)$. Dengan kata lain, butir akan sangat informatif ketika parameter tingkat kesulitan butir itu benar-benar cocok dengan tingkat kemampuan peserta (person's trait level).
Butir juga tidak sama informatifnya disepanjang bentang (range) trait. Beberapa butir bagus dalam membedakan peserta tes pada ujung skala (trait kontinum) tapi buruk dalam membedakan peserta tes pada pangkal skala (Fraley, Waller \& Brennan, 2000: 352).

Selanjutnya berikut contoh dua butir Soal Try-Out Bahasa Inggris SMP di Kota Makassar yang memiliki fungsi informasi yang berbeda: 


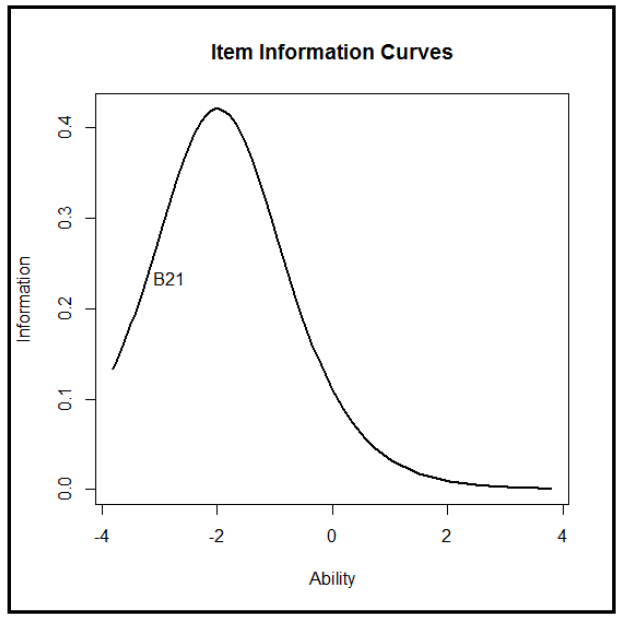

Butir 21

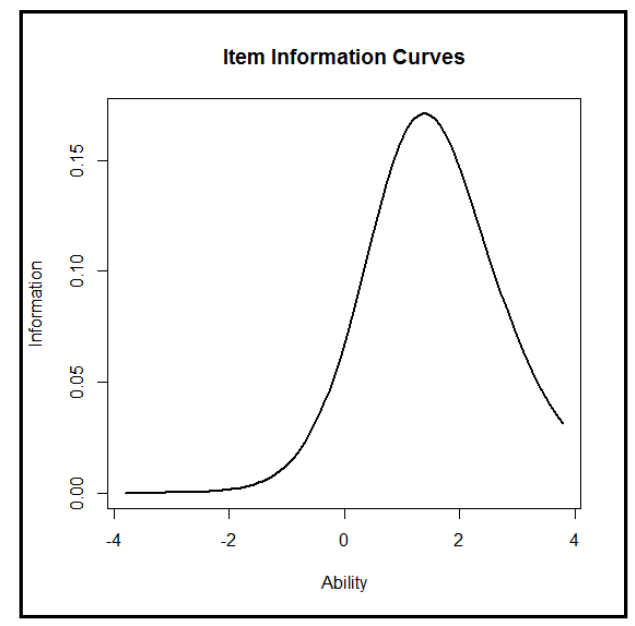

Butir 20

Gambar 3.3.3 Contoh 2 Fungsi Informasi Butir Soal Try-Out SMP di Kota Makassar berdasarkan Model Logistik 3 Parameter

Pada Gambar 3.3.3 tersebut disajikan dua Fungsi Informasi dari butir yang berbeda. Berdasarkan kurva di atas, butir 21 memberi informasi yang maksimal jika dikenakan pada peserta yang berkemampuan rendah atau cocok diterapkan untuk peserta yang berkemampuan rendah. Sebaliknya butir 20 justru memberi informasi yang maksimal jika dikenakan pada peserta tes yang berkemampuan tinggi sehingga cocok diberikan kepada peserta yang berkemampuan tinggi.

\section{Pembahasan}

Model logistik 3 parameter merupakan model estimasi butir yang sempurna, karena mengontrol 3 parameter butir secara bersama yaitu parameter tingkat kesukaran, parameter daya beda butir dan parameter tebakan pada butir sehingga hasil yang diperoleh lebih akurat dan mendalam.

Hasil estimasi terhadap tingkat kesukaran butir menunjukkan bila ada
10 butir (20\%) yang mesti ditinjau ulang. Dan lebih banyak lagi (29 butir/58\%) yang perlu diperbaiki kemampuannya dalam membedakan kemampuan peserta tes. Hasil penelitian ini juga menunjukkan begitu banyak butir (19 butir/38\%) yang memiliki tingkat tebakan cukup tinggi. Naga (1998: 34) mengatakan tingkat kesukaran butir sering dikaitkan dengan kemampuan responden dan taraf sukar butir (sukar, sedang, dan mudah). Butir yang telalu mudah memberikan hasil yang buruk sehingga digolongkan butir kategori tidak baik, begitupula butir soal yang terlalu sulit juga akan memberi hasil yang buruk dan tentunya berada pada kategori tidak baik.

Tingkat kesulitan butir $\left(b_{i}\right)$ mewakili tingkat laten trait (kemampuan) yang dibutuhkan individu peserta tes untuk mencapai peluang 0.50 dalam menjawab butir dengan benar. Sebagai contoh, jika sebuah butir memiliki tingkat kesulitan 1.00, maka individu dengan tingkat trait (kemampuan) 1.00 memiliki peluang 
$50 \%$ menjawab butir tersebut dengan benar.

Butir yang memiliki tingkat kesulitan tinggi cenderung hanya dijawab dengan benar oleh individu yang berkemampuan tinggi (biasanya dijawab benar oleh sedikit individu). Dan sebaliknya, butir yang memiliki tingkat kesulitan rendah, cenderung dijawab dengan benar oleh individu berkemampuan sedang dan atau tinggi (biasanya dijawab benar oleh banyak individu (Fraley, Waller \& Brennan, 2000: 351).

Mengenai daya beda. Baker (2001: 35) membagi level daya beda dalam 7 kategori, sebagai berikut:

\begin{tabular}{|c|c|}
\hline Value & Label \\
\hline 0 & None \\
\hline $0.01-0.34$ & Very Low \\
\hline $0.35-$ & Low \\
0.64 & \\
\hline $0.65-$ & Moderate \\
1.34 & \\
\hline $1.35-1.69$ & High \\
\hline$>1.70$ & Very High \\
\hline+ & Perfect \\
\hline infinity & \\
\hline
\end{tabular}

Tabel 4.1: Label Nilai Parameter Daya Beda Butir (Baker, 2001:35)

Parameter daya beda butir $\left(a_{i}\right)$ mewakili kemampuan butir untuk membedakan diantara peserta tes yang memiliki tingkat trait yang bersebelahan (contiguous). Secara teoritis, parameter ini membentang dari 0.00 sampai angka positif yang tak terbatas, meski dalam banyak aplikasi, bentangan yang ditemukan biasanya lebih pendek. Khusus dalam penaksiran personality, attitudes, and interpersonal behaviors, daya beda butir sering berkisar antara 0.50 sampai 2.50 (Gray-Little, Williams, \&
Hancock, 1997; Hambleton et al., 1991; Kim \& Pilkonis, 1999; Reise \& Waller, 1990, dalam Fraley, Waller \& Brennan, 2000: 351). Dalam IRT, butir yang memiliki daya beda tinggi juga memiliki indikator yang laten trait yang lebih baik ketimbang butir yang memiliki daya beda rendah. (Fraley, Waller \& Brennan, 2000: 352)

Menurut Sudaryono (2013: 3), butir yang memiliki ciri dapat dijawab dengan betul oleh kebanyakan responden yang berkemampuan tinggi, dan tidak dapat dijawab dengan betul oleh kebanyakan responden yang berkemampuan rendah, merupakan butir yang baik.

Daya beda butir harus mampu membedakan peserta didik yang telah menguasai materi yang ditanyakan dan peserta didik yang belum menguasai materi yang ditanyakan. Nilai yang tertera mengindikasikan seberapa baik butir bersangkutan memisahkan antara responden yang berkemampuan rendah dan responden berkemampuan tinggi.

Tingkat daya beda ditunjukkan oleh kecuraman kurva. Semakin curam kurvanya, semakin baik daya beda butirnya (Thorpe dan Favia, 2012: 7). Ditambahkan Fraley, Waller \& Brennan (2000: 352), kemampuan butir dalam membedakan peserta yang memiliki tingkat/level trait yang hampir sama, adalah lebih tinggi di daerah theta $(\theta)$ yang sejajar dengan tingkat kesulitan butir.

Sementara mengenai parameter tebakan $\left(c_{i}\right)$, menurut Hullin, (1983: 36) pada suatu butir tes, nilai $c_{i}$ berkisar antara 0 dan 1 . Suatu butir dikatakan baik jika nilai $c_{i}$ tidak lebih dari $1 / k$, dengan $k$ banyaknya pilihan. Jadi misalkan pada suatu perangkat tes pilihan ganda Try-Out Bahasa Inggris di SMP Kota Makassar 
dengan 4 pilihan atau opsi untuk setiap butir tesnya, butir ini dikatakan baik jika nilai $c i$ tidak lebih dari 0,25 .

\section{Kesimpulan}

Soal Try-Out Bahasa Inggris SMP di
Kota Makassar memiliki tingkat kesukaran butir dan tingkat tebakan yang masih bisa ditoleransi sehingga bisa dikatakan baik, namun daya beda butirnya tergolong buruk. Secara umum Soal Try-Out Bahasa Inggris SMP di Kota Makassar memberi informasi yang maksimal jika dikenakan pada peserta tes yang berkemampuan sekitar 1.9 hingga 2.2 .

\section{Daftar Pustaka}

Agustini. 2012. Analisis Pemahaman Konsep Matematika Siswa Melalui Tes dan Wawancara. Tesis. Makassar: PPs UNM.

Asmin. 2004. Implementasi Teori Responsi Butir dan Fungsi Informasi Butir Tes dalam Pengujian Hasil Belajar Akhir di Sekolah. Jurnal Pendidikan dan Kebudayaan, X(48), 234-245.

Aiken, Lewis R. 1994. Psychological Testing and Assessment. Boston: Allyn and Bacon, Inc.

An, Xinming An \& Yung, Yiu-Fai. 2014. Item Response Theory: What It Is and How You Can Use the IRT Procedure to Apply It. Artikel. SAS Institute Inc: Paper SAS364-2014. Diperoleh 10 Agustus 2014 dari http://support.sas.com/resources/papers/proceedings14/SAS364-2014.pdf.

Baker, Frank B. 2001. The Basics of Item Response Theory. College Park, MD: ERIC Clearinghouse on Assessment and Evaluation. Diperoleh 10 Agustus 2014 dari http://edres.org/irt/baker/.

Crocker, Linda \& Algina, James. 1986. Introduction to classical and modern test theory. New York: Holt, Rinehart and Winston, Inc.

Djaali \& Pudji. M. 2008. Pengukuran Dalam Bidang Pendidikan. Jakarta: Gramedia Widiasarana Indonesia.

Edwards, Michael C. 2009. An Introduction to Item Response Theory Using the Need for Cognition Scale. Journal Compilation, Social and Personality Psychology Compass, 3(4), 507-529. Diperoleh 10 Agustus 2014 dari http://faculty.psy.ohio-state.edu/edwards/documents/Edwards2009.pdf.

Enang, Hijriah. 2014. Analisis Kualitas Soal Seleksi Penerimaan Peserta Didik Baru $(P P D B)$ di SMPN 32 Makassar. Tesis. Makassar: PPs UNM. 
Fan, Xitao. 1998. Item Response Theory and Classical Test Theory: an Empirical Comparison of Their Item/Person Statistics. Educational and Psychological Measurement, 58(3), 357(25).

Fraley, R. Chris; Waller, Niels G; \& Brennan, Kelly A. 2000. An Item Response Theory Analysis of Self-Report Measures of Adult Attachment. Journal of Personality and Social Psychology, 78(2), 350-365. Diperoleh 10 Agustus 2014 dari http://www.web-research-design.net/PDF/FW\&B2000.pdf.

Hambleton, Ronald K. 1990. Item Response Theory: Introduction and Bibliography. Psychotema, 2(1), 97-107. Diperoleh 10 Agustus 2014 dari http://www.psicothema.com/pdf/647.pdf.

Hambleton, Ronald K; Swaminathan, H; \& Jane Rogers, H. 1991. Fundamentals of Item Response Theory. London: Sage Publications.

Hullin, C. L., et al. 1983. Item response theory : Application to psichologycal measurement. Homewood, IL : Dow Jones-Irwin.

Lord, Frederick M. 1990. Aplications of Item Response Theory to Practical Testing Problems. New Jersey: LawrenceErlbaum Associates, Publishers.

Naga, Dali S. 1991. Pengantar Teori Sekor Pada Pengukuran Pendidikan. Jakarta: Gunadarma.

Naga, Dali S. 1992. Pengantar Teori Sekor Pada Pengukuran Pendidikan. Jakarta: Besbats.

Naga, Dali S. 1998, Karakteristik Butir pada Alat Ukur Model Dikotomi, Arkhe: Jurnal Ilmiah Psikologi, III(4), 34-42.

Magno, Carlo. 2009. Demonstrating the Difference between Classical Test Theory and Item Response Theory Using Derived Test Data. The International Journal of Educational and Psychological Assessment, 1(1), 1-11.

Mansyur, Harun \& Rasyid. 2009. Asesmen Pembelajaran di Sekolah. Yogyakarta: Multi Pressindo.

Mardapi, D. 2007. Teknik Penyusunan Instrumen Tes dan Non Tes. Yogyakarta: Mitra Cendekia.

Mardawiah. 2011. Analisis Kualitas Soal Try-Out IPA Tahun Pelajaran 2011/2012 Pada Peserta Didik SMP di Kota Makassar. Tesis. Makassar: PPs UNM.

Messick, S. 1989. Educational Measurement, $3^{\text {rd }}$ edition, New York : Macmillan. 
Rasyid, Harun \& Mansyur. 2007. Penilaian Hasil Belajar. Bandung: CV Wacana Prima.

Ruslan. 2009. Validitas Isi. Buletin Pa' Biritta No. 10. Tahun VI September 2009.

Ruslan. 2014. Pengukuran Variabel Laten dalam Analisis Kebijakan (Orasi Ilmiah Guru Besar). Makassar: Badan Penerbit UNM.

Salam, S. \& Bangkona, D. 2010. Pedoman Penulisan Tesis dan Disertasi. Makassar: PPs UNM.

Sharkness, Jessica \& DeAngelo, Linda. 2011. Measuring Student Involvement: A Comparison of Classical Test Theory and Item Response Theory in the Construction of Scales from Student Surveys. Research in Higher Education, 52, 480-507.

Sudaryono. 2013. Teori Responsi Butir. Yogyakarta: Graha Ilmu.

Sudaryono. 2013. Implementasi Teori Responsi Butir (Item Response Theory) Pada Penilaian Hasil Belajar Akhir di Sekolah.

Surapranata, Sumarna. 2004. Analisis, Validitas, Reliabilitas Dan Interpretasi Hasil Tes. Rosdakarya: Bandung.

Susetyo, Budi. 2007. Komparasi Fungsi Informasi Butir Model L2P Bentuk Tes Objektif Empat Pilihan Jawaban dan TIga Pilihan Jawaban Pada Mata Pelajaran Sains di SD dan SMP ditinjau dari Perkembangan Kognitif operasional Kongkrit (SD) dan Operasional Formal (SMP). Disertasi. Jakarta: UNJ.

Thorpe, Geoffrey L. \& Favia, Andrej. 2012. Data Analysis Using Item Response Theory Methodology: An Introduction to Selected Programs and Applications. Artikel. Psychology Faculty Scholarship: Paper 20. Diperoleh 10 Agustus 2014 dari http://digitalcommons.library.umaine.edu/psy_facpub/20.

Tim Pengembangan Prodi PEP PPs UNM. Sistematika Penulisan Proposal dan

Laporan Tesis. Tidak diterbitkan. Makassar: Prodi PEP PPs UNM. 